UDC 629.3.025.2 (045)

${ }^{1}$ V. M. Syneglazov,

${ }^{2}$ V. O. Glukhov

\title{
PARTIAL CRITERIA SYSTEM OF ESTIMATION OF PILOT PREPAREDNESS LEVEL BEFORE SIMULATOR TRAINING
}

\begin{abstract}
${ }^{1,2}$ Educational-Scientific Institute of Information-Diagnostics Systems, National Aviation University, Kyiv, Ukraine

E-mail: ${ }^{1}$ svm@nau.edu.ua

Abstract-The paper deals with partial criteria system of estimation of pilot preparedness level before simulator training that allow to evaluate the ability to perform operations of helicopter control by the pilot. Presented the formalized problem statement, which includes the effectiveness criteria of training on the simulator. Provided the algorithm of of pilot preparedness evaluation on the basis of partial criteria. Presented a comparative analysis of calculation results of pilot preparedness level evaluation by this algorithm. The proposed approach provides optimal distribution of trainingload for the pilot based on his executive preparedness.
\end{abstract}

Index terms - Partial criterion; automated system of helicopter pilots simulator training; effectiveness criterion; aviation simulator.

\section{INTRODUCTION}

The problem of increasing the effectiveness of pilot training simulator is actual. It is connected with a constant process complication of aircraft control, including helicopters.

The analysis of plane crashes and accidents of the last few years shows that the causes of such situations can be joined into the following groups.

1. The human factor $-50-60 \%$.

2. Technical failure $-15-30 \%$.

3. External influence $-10-20 \%$.

4. Other (unclarified) $-5-10 \%$.

From this analysis it can be concluded that the main cause of occurrence of accidents is a pilot, as an element of the man-machine system.

The relevance of the development of computer simulators consists in two trendy tendencies of recent years. Firstly, there is a need for qualitative improvement of pilots training, caused by constant complication of helicopter systems and new control systems. Secondly, information technologies provide the opportunity to create new approaches and, consequently, training systems on the simulator, which exceeds for effectiveness all known.

For pilots training it is need to use modern methods and technologies, such as a training simulator. Using the simulator to maintain the pilot's qualification at the required level facilitates timely manifestation of necessity of increase of the professional level.

During the development of computer simulators main difficulty lies in the extreme mobility of simulator training technology, in which each element of the system should be modeled at a high level. Indeed, having advanced mathematical models of processes, and without solving the problem of their relationship with the pilot in real time, it is impossible to achieve effective form of control skills. At the same time, having models and powerful hardware and software simulator platform, but without having an adequate method of computer training, you can not rely on the consolidation and transfer of acquired skills and knowledge to real-life practice.

Another problem is that it is impossible to seek training components of training systems only in the technical framework and that the formation, consolidation and positive transference of acquired skills is determined, first of all, the degree of similarity of the pilot activities in the training process. However, there is a certain gap between the developments in the field of modeling of dynamic processes, the creation of user interfaces and support instruction tools on the one hand, and cognitive researches of mechanisms of skills formation and transfer on the other hand.

Under the cognitive approach to the study of human-machine interaction understood the installation to identify the mechanisms of perception and interpretation of the information that a person receives from the technical system as well as the processing of this information in the decisionmaking process.

Under these conditions, theoretically grounded formulation and solution of problems of typical piloting, optimally combines standard and unique components of the system and the creation of a methodology of pilots computer training, are very relevant. 
To create a qualitatively new system of helicopter pilots training, it is necessary to learn research methods based on the use of mathematical modeling of processes and devices, automatic control theory, the theory of artificial intelligence, cognitive engineering methods and statistical data processing [2].

\section{Problem Statement}

To solve multicriteria task it is necessary to find an optimum on the $\mathbf{K}$ criteria, and the task itself is formally written as:

$$
y=f(x)=\left(f_{1}(x), f_{2}(x), \ldots, f_{K}(x)\right) \rightarrow \mathrm{opt},
$$

$x=\left(x_{1}, x_{2}, \ldots, x_{N}\right) \in X \quad-$ is a solution vector satisfying the constraints $\mathbf{M}, g(x)=\left(g_{1}(x), g_{2}(x)\right.$, $\left.\ldots, g_{M}(x)\right) \geq 0 ; \quad y=\left(y_{1}, y_{2}, \ldots, y_{K}\right) \in Y \quad-\quad$ is $\quad$ an objective functions vector.

Here $X$ is a solution space and $Y$ is aims or criteria space. Limits $g(x) \geq 0$ define the set of allowable solutions of the task.

Allowable set $\mathbf{D}$ is defined as a set of solution vectors $\mathbf{x}$, that satisfy the constraints $g(x)$ :

$$
\mathbf{D}=\{\mathbf{x} \in \mathbf{X} \mid g(x) \geq 0\} .
$$

Then allowable area in the aims space $D$ image is denoted through $Y_{f}=f(D)=\bigcup_{x \in D}\{f(x)\}$.

\section{SUBSTANTIATION OF TRAINING CRITERIA}

The system of partial criteria of pilot performance effectiveness is built on the basis of knowledge of the numerical values of actual $i_{k}(t)$ and normative $g_{k}(t), k=\overline{1, n}$ criteria. Under real conditions it is necessary take into account the intensity of work of the pilot:

$$
U(t)=\frac{i_{k}(t)}{g_{k}(t)} .
$$

In technical systems the criterion $g_{k}$ is the lower limit and the system tries not to exceed it. Then the intensity of link work will be equal to

$$
U(t)=\frac{g_{k}(t)}{i_{k}(t)} .
$$

The effectiveness of the pilot operation is evaluated differently in different hierarchical levels. From the position of the system of the highest hierarchical level, the pilots operation effectiveness is estimated by the degree of link using $U(t)$. The higher it is, then the link work that characterizes the pilot, is better. From the position of the reporting pilot, his operational capability is higher if better the fulfilled planned norm, regardless of the used resources. Accordingly, the result of the pilot operation in the reduced units from the position a system higher hierarchical level, is calculated accordingly to level of link that characterizes a pilot, with respect to the objective function. And from the position of reporting pilot in accordance with the objective function.

In the general case, the system of partial criteria includes three types of criteria, which will evaluate the pilot:

Depending on the rated parameter limit, partial criteria of activity effectiveness can be written as:

-from the system position of a higher hierarchical level;

-from the position of the considered pilot (crew);

-from the position of interests coordination of the pilot and crew [2], [4].

a) at normalization with an upper limit:

- from the position of higher hierarchical level system:

$$
\begin{gathered}
P_{k}(t)=U_{k}(t) \cdot i_{k}(t) \approx \frac{i_{k}^{2}(t)}{g_{k}(t)} \\
V_{k}(t)=\frac{P_{k}(t)}{g_{k}(t)}=\frac{i_{k}^{2}(t)}{g_{k}^{2}(t)},
\end{gathered}
$$

where $P_{k}(t)$ is the partial criterion in the given units;

$V_{k}(t)$ is the partial criterion in the relative units;

- from the position of the link:

$$
\begin{gathered}
P_{k}^{*}(t)=g_{k}(t)+m \frac{\left[g_{k}(t)-i_{k}(t)\right]^{2}}{g_{k}(t)} ; \\
V_{k}^{*}(t)=\frac{P_{k}^{*}(t)}{g_{k}(t)},
\end{gathered}
$$

where $m=1$, if $U_{k}(t) \geq 1, m=-1$, if $U_{k}(t)<1$;

- from the position of interests coordination of system with higher hierarchical level of level and link that characterizes a pilot

$$
P_{k}^{* *}(t)=\frac{2 P P^{*}(t)}{P+P^{*}(t)}
$$

and

$$
V_{k}^{* *}(t)=\frac{2 V V^{*}(t)}{V+V^{*}(t)}, \text { or } V_{k}^{* *}(t)=\frac{P_{k}^{* *}}{g_{k}} .
$$

b) at normalization with a lower limit: from the position system of higher level 


$$
P_{k}(t)=U_{k}(t) g_{k}(t)=\frac{g_{k}^{2}(t)}{i_{k}(t)} ; \quad V_{k}(t)=\frac{P_{k}(t)}{i_{k}(t)}=\frac{g_{k}^{2}(t)}{i_{k}^{2}(t)} ;
$$

- from the position of link

$$
P^{*}(t)=g_{k}(t)+m \frac{\left[g_{k}(t)-i_{k}(t)\right]^{2}}{i_{k}(t)},
$$

where $m=1$ if $U_{k}(t) \geq 1 ; m=-1$ if $U_{k}(t)<1$;

- from the position of interests coordination of the link and systems

$$
P_{k}^{* *}(t)=\frac{2 P_{k}(t) P_{k}^{*}(t)}{P_{k}(t)+P_{k}^{*}(t)} ; \quad V_{k}(t)=\frac{2 V_{k}(t) V_{k}^{*}(t)}{V_{k}(t)+V_{k}^{*}(t)}
$$

or

$$
V_{k}^{* *}(t)=\frac{P_{k}^{* *}(t)}{i_{k}(t)} .
$$

For convenience and formalization denote these criteria as: $U_{\mathrm{x}}(t)=I_{1} ; P_{\mathrm{x}}(t)=I_{2} ; V_{\mathrm{x}}(t)=I_{3}$.

It is known that the training process takes place in the course of joint activities of a trainer and a trained. For the automation of training process control is necessary to research activities of both to identify those of its elements, which automation is practically feasible.

The aim of efficiency improving is mastering by pilots of all necessary skills that ensure minimization (maximization) next during a fixed period of training time $T$.

The effectiveness criteria of training by taking into account factors of accidents (number of accidents of various kinds) can be written as:

$$
I_{4}=\sum_{i=1}^{p} n_{i}
$$

where $n_{i}$ is the number of accidents due to poor performance of the $i$ th single skill; $p$ are total number of skills, required to a helicopter pilot for the successful execution of flights.

The dependence of the mistake criterion of training time can be defined as:

$$
I_{5}=P(t, T)=1-\exp (-a t)+\exp (-a t) \exp (-b T),
$$

where $I_{5}=P(t, T)$ is the likelihood of wrong actions (relating to a single training) on a real helicopter by trained pilot during time $t$, if it is already passed the time $\mathrm{T}$ since the training. Parameters $a$ and $b$ are the coefficients generally dependent on individual characteristics of the pilot, such as seniority, experience, intelligence, education, resistance to stress and on the characteristics of productive activity, such as the presence of stress, the level of monotony of activity, proximity of the training conditions to real conditions of helicopter piloting.

Evaluation of possible prevented damage $I_{6}$ can be made by expert estimates. To estimate the $I_{6}$ average value of damage $S_{c p j}$ from accident of $Y_{j}$ $(j=1 \ldots R)$ type multiplies by the number of exploited helicopters $N$

$$
I_{6}=N \sum_{j=1}^{R} S_{c p j}
$$

One approach to the formation of the criterion that determines the effectiveness of the training on a simulator is to give to each single training a certain numerical value, for example, the average damage in the commission of mistake by pilot, related to single training and its corresponding single skill on a real helicopter. This value can also be obtained from the statistics correctly enough due to lack of baseline information, but the use of a method of expert estimations allows to bring quite reasonable scientific basis under this value.

As a criterion of effectiveness can be used a criterion which takes into account an academic progress of trained pilots on the simulator. The research shows that during the skills mastering, application of criterion of total academic performance maximum does not exclude the possibility of unacceptably low marks Application of the guarantee multiplicative criterion will provide a higher quality of training without a strong reduction of certain assessments, although it complicates the process of the given problem solving

$$
I_{7}=k_{1} \sum_{i=1}^{n} x_{i}+k_{2} \prod_{i=1}^{n} x_{i}
$$

where $x_{i}$ it is normalized quality assessment of the mastering of one skill that lies within the limits $[0,1] ; I_{7}$ it is total integral criterion of automated training.

Achievement of this goal can ensured through the creation of an automated system of helicopter driving training control and optimization of the training plan by defining the required time of single skills mastering [3].

\section{MULTICRITERIA OPTIMIZATION PROBLEM SOLUTION}

As genetic algorithms belong to the multi-point search methods, optimization problem with them can be solved even in case of the multimodal nature of the objective functions. Moreover, they are also applicable to the problems with discrete search 
space. Therefore, genetic algorithms are one of the most powerful optimization mechanisms, while fairly simple in use [1], [7], [11].

Algorithms based on an evolutionary approach to the multicriteria tasks solution can get rid of the main disadvantages of the classical methods, as are appropriate for large-scale problems and able to grab a Pareto-optimal points, even after a single algorithm iteration. By sustaining the solutions population and making use of the concept of Pareto optimality, evolutionary algorithms can process a variety of Pareto-optimal solutions in parallel. So, unlike most classical approaches to multicriteria optimization, when for every single point you must make a separate iteration of Pareto-optimal solutions search algorithm, the application of evolutionary approach to vector optimization through incorporated in genetic algorithms multimodal search, you may receive different Pareto set points in a single run of the algorithm. This fact is a clear advantage of evolutionary approach to solving the problems of multicriteria optimization over traditional methods of solving them. As a result, genetic algorithms are very effective means of solving optimization problems, especially problems with vector criterion.

The genetic algorithm used for a particular purpose shall consist of the following main components [7].

1. Representation of potential solutions to the problem.

2. The method, which creates an initial population of possible solutions.

3. Solutions evaluation function, which plays the role of the external environment, determining solutions in terms of their suitability.

4. Genetic operators that change the composition of the children (descendants).

5. The values of various parameters that are used by genetic algorithm (population size, the probability of genetic operators being applied, etc.).

In the development of specific methods for solving problems of multicriteria via genetic algorithm, the emphasis is on the modification of purpose suitability and selection with maintenance of the population diversity stages.

The most effective approach for the solution of this problem is Strength Pareto Evolutionally Algorithm (SPEA) method in which:

- to assign individuals a scalar value of fitness Pareto dominance concept is used;

- individuals non-dominating with respect to other members of the population are stored externally in a special external set;
- to reduce the number of individuals stored in an external set, clustering is performed, which in turn does not influence the process of searching the acquired properties in individuals.

Strength Pareto Evolutionally Algorithm uniqueness and advantages of the method lies in the fact that:

- it combines the above approaches in a single algorithm;

- fitness of each individual in the populations in this method is determined only with respect to the external set individuals regardless of whether the individuals in population dominate each other;

- despite the fact that the "best" individuals obtained in the previous generations are stored separately - in the external set - they are still involved in the selection;

- and to prevent premature convergence the SPEA method uses a special mechanism for the formation of niches where the division of general fitness is carried out not in the sense of distance between individuals but based on Pareto dominance.

In solving the conditional multiobjective problem the final points should not just get in the Pareto set but comply with constraints - to lie in the allowable area. In this case, depending on the location of the allowable area in the search space, obtained Paretodecision of conditional problem can change relatively to unconstrained problem solution.

\section{EXAMPLE OF PILOT PREPAREDNESS LEVEL ESTIMATION}

According to equations (1) - (6) it is possible to calculate the next example.

Example: the pilot of the 29 fulfilled skills correctly executed 22 , then $i_{k}=22, g_{k}=29$.

$$
\begin{gathered}
P=\frac{i_{k}^{2}}{g_{k}}=\frac{22^{2}}{29}=16.69 ; \\
V=\frac{P}{g_{k}}=\frac{16.69}{29}=0.58 ; \\
P^{*}=g_{k}+m \frac{\left(g_{k}-i_{k}\right)^{2}}{g_{k}} ; \\
U=\frac{i_{k}}{g_{k}}=\frac{22}{29}<1, \text { thus } m=-1,
\end{gathered}
$$

then

$$
\begin{gathered}
P^{*}=29-\frac{(29-22)^{2}}{29}=27.31 ; \\
V^{*}=\frac{P^{*}}{g_{k}}=\frac{27.31}{29}=0.942 ;
\end{gathered}
$$




$$
\begin{gathered}
P^{* *}=\frac{2 \cdot P \cdot P^{*}}{P+P^{*}}=\frac{2 \cdot 16.69 \cdot 27.31}{16.69+27.31}=20.718 ; \\
V^{* *}=\frac{P^{* *}}{g_{k}}=\frac{20.718}{29}=0.714 .
\end{gathered}
$$

\section{CONCLUSIONS}

The level of pilot preparedness can be represented as the corresponding values of actual parameters according to normalized in the current circumstances within the prescribed limits.

Pilot's actions in the expected conditions must be considered from the standpoint of interests reconciling of the system of higher hierarchical level and link.

The system of criteria of preparedness level assessment, includes:

- a group of private criteria corresponding to normalized criteria;

- a group of common criteria for the criteria groups that combine private criteria according to certain characteristics;

- a group of common criteria in tasks at a certain stage;

- a group of common criteria by stages;

- general criterion (efficiency criterion) of preparation of ensure the piloting readiness in the anticipated operating conditions of air transport.

\section{REFERENCES}

[1] D. I. Batishchev, Genetic algorithms for solving extreme problems. A manual, Voronezh: Voronezh State Technical University, 1995, 69 p.

[2] B. S. Bloom, The sigma Problem: The Search for Methods of Group Instruction as Effective as One-to-
One Tutoring. Education Researcher. 1984, no. 13, $3 \mathrm{p}$.

[3] R. R. Burton, and J. Brown, "Toward a naturallanguage capability for computer- assisted instruction". Procedures for instructional system development, Edited by H. F. O' Neil, New York: Academic, 1979, $273 \mathrm{p}$.

[4] A. Collins, and A. L. Stevens, Goals and strategies of interactive teachers, Advances in instructional psychology, Edited R. Glaser, Hillsdale, NJ: Erlbaum, 1980, $127 \mathrm{p}$.

[5] W. G. Dahlstrom, and G. S. Welsh, An MMPI handbook. Minneapolis, 1963.

[6] J. H. Holland, Adaptation in natural and artificial systems. An introductory analysis with application to biology, control and artificial intelligence. London: Bradford book edition, 1994, $211 \mathrm{p}$.

[7] S. A. Isaev, Popularly about the Genetic Algorithms. URL: http://saisa.chat.m/ga/ga-pop.html\#top

[8] V. M. Sineglazov and Ju. M. Shmelev, "Estimation of helicopter pilots training efficiency in the simulator". Electronics and Control Systems, no. 4(38), Kyiv, NAU, pp. 104-107, 2013.

[9] V. M. Sineglazov and Ju. M. Shmelev, "Improving the efficiency of helicopter pilots training in the simulator". Electronics and Control Systems, no. 3(37), Kyiv, NAU, pp. 120-123, 2013.

[10] V. M. Sineglazov and Ju. M. Shmelev. "Simulator training optimization". Electronics and Control Systems, no. 1(39), Kyiv, NAU, pp. 63-66, 2014.

[11]A. Starikov, BaseGroup Labs. Genetic algorithms mathematical apparatus. URL: http://vyww. basegroup.ru/genetic/rnath.htrri.

Received March 02, 2016

Sineglazov Viktor. Doctor of Engineering. Professor.

Educational-Scientific Institute of information-diagnostic systems, National Aviation University, Kyiv, Ukraine. Education: Kyiv Polytechnic Institute, Kyiv, Ukraine (1973).

Research area: Air Navigation, Air Traffic Control, Identification of Complex Systems, Wind/Solar power plant. Publications: more than 500 papers.

E-mail: svm@nau.edu.ua

Glukhov Vitaliy. Bachelor.

Education-Scientific Institute of Information-Diagnostics Systems, National Aviation University, Kyiv, Ukraine.

Education: National Aviation University, Kyiv, Ukraine. (2016)

Research interests: vehicles simulators, automated training systems.

В. М. Синєглазов, В. О. Глухов. Система частинних показників оцінювання рівня підготовки пілота перед заняттям на тренажері

Розглянуто систему частинних критеріїв оцінювання рівня підготовки пілота перед заняттям на тренажері, що дає змогу оцінити можливість виконання пілотом операцій у процесі керування вертольотом. Представлено формалізовану постановку задачі, яка включає в себе критерії ефективності навчання на тренажері. Надано алгоритм оцінювання рівня підготовки пілота на основі системи частинних критеріїв. Представлено порівняльний аналіз результатів підрахунку оцінки рівня підготовки пілота за даним алгоритмом. 
Запропонований підхід забезпечує оптимальний розподіл навчального навантаження для пілота на основі його виконавчої готовності.

Ключові слова: частинний критерій; автоматизована система навчання пілотів вертольотів; критерій ефективності; авіаційний тренажер.

Синєглазов Віктор Михайлович. Доктор технічних наук. Професор.

Навчально-науковий інститут інформаційно-діагностичних систем, Національний авіаційний університет, Київ, Україна.

Освіта: Київський політехнічний інститут, Київ, Україна (1973).

Напрям наукової діяльності: аеронавігація, управління повітряним рухом, ідентифікація складних систем, вітроенергетичні установки.

Кількість публікацій: більше 500 наукових робіт.

E-mail:svm@nau.edu.ua

Глухов Віталій Олександрович. Бакалавр.

Навчально-науковий інститут інформаційно-діагностичних систем, Національний аваційний університет, , Київ, Україна.

Освіта: Нацональний авіаційний університет, Київ, Україна (2016).

Напрям наукової діяльності: тренажери транспортних засобів, автоматизовані навчальні системи.

В. М. Синеглазов, В. О. Глухов. Система частных показателей оценивания уровня подготовленности пилота перед занятием на тренажере

Рассмотрена система частных критериев оценивания уровня подготовленности пилота перед занятием на тренажере, что позволяет оценить возможность исполнения пилотом операций в процессе управления вертолётом. Представлена формализованная постановка задачи, которая включает в себя критерии эффективности обучения на тренажере. Показан алгоритм оценивания уровня подготовленности пилота на основании системы частных критериев. Представлен сравнительный анализ результатов подсчета оценки уровня подготовленности пилота в соответствии с данным алгоритмом. Предложенный подход обеспечивает оптимальное распределение нагрузки обучения для пилота на основании его исполнительной готовности.

Ключевые слова: частный критерий; автоматизированная система обучения пилотов вертолётов; критерий эффективности; авиационный тренажер.

Синеглазов Виктор Михайлович. Доктор технических наук. Профессор.

Учебно-научный институт информационно-диагностических систем, Национальный авиационный университет, Киев, Украина.

Образование: Киевский политехнический институт, Киев, Украина (1973).

Направление научной деятельности: аэронавигация, управление воздушным движением, идентификация сложных систем, ветроэнергетические установки.

Количество публикаций: более 500 научных работ.

E-mail:svm@nau.edu.ua

Глухов Виталий Александрович. Бакалавр.

Учебно-научный институт информационно-диагностических систем, Национальный авиационный университет, Киев, Украина.

Образование: Национальный авиационный университет, Киев, Украина (2016).

Направление научной деятельности: тренажеры транспортных средств, автоматизированные обучающие системы. 